\title{
The first record of Pseudanthobothrium hanseni Baer, 1956 (Cestoda: Echeneibothriidae) in the White Sea
}

\author{
I.I. Gordeev ${ }^{1,2}$, T.A. Polyakova ${ }^{3}$ \\ ${ }^{1}$ Lomonosov Moscow State University, Leninskiye Gory 1/12, 119234, Moscow, Russia. \\ ${ }^{2}$ Russian Federal Research Institute of Fisheries and Oceanography, Verkhn. Krasnoselskaya Str. \\ 17, 107140, Moscow, Russia.E-mail: gordeev_ilya@bk.ru \\ ${ }^{3}$ The A.O. Kovalevsky Institute of Biology of the Southern Seas of RAS, Nakhimov Av. 2, 299011, \\ Sevastopol, Russia.E-mail: polyakova-acant@yandex.ru
}

ABSTRACT: Cestodes are fairly common in teleost fishes in the White Sea but have never been previously recorded there in elasmobranchs. We found seven individuals of the cestode Pseudanthobothrium hanseni in a single specimen of the starry ray Amblyraja radiata caught in the White Sea. Molecular analysis based on partial 28S rDNA sequence confirmed that our specimens belonged to this species. Their morphological and morphometric features were compared with the descriptions of $P$. hanseni available in the literature. Specimens of $P$. hanseni from the White Sea were smaller than those from the other areas, had fewer testes, and the vitelline follicles in their mature terminal proglottids did not reach the proglottid's posterior end. The reasons of these differences are unclear, but the low salinity of the White Sea may play a certain role. To sum up, in this study we provided the first record of a cestode in an elasmobranch in the White Sea and added a new point to the distribution of $P$. hanseni.

How to cite this article: Gordeev I.I., Polyakova T.A. 2020. The first record of Pseudanthobothrium hanseni Baer, 1956 (Cestoda: Echeneibothriidae) in the White Sea // Invert. Zool. Vol.17. No.4. P.361-369. doi: 10.15298/invertzool.17.4.02

KEY WORDS: tapeworm, skate, White Sea, 28S rDNA, helminth, Arctic.

\section{Первая находка Pseudanthobothrium hanseni Baer, 1956 (Cestoda: Echeneibothriidae) в Белом море}

\section{И.И. Гордеев ${ }^{1,2}$, Т.А. Полякова ${ }^{3}$}

\footnotetext{
${ }^{1}$ Московский государственный университет им. М.В. Ломоносова, Ленинские горы д. 1/12, Москва, 119234, Россия.

${ }^{2}$ Всероссийский научно-исследовательский институт рыбного хозяйства и океанографии, ул. Верхняя Красносельская 17, Москва, 107140, Россия._E-mail: gordeev_ilya@bk.ru

${ }^{3}$ Институт биологии южных морей РАН им. А.О. Ковалевского, пл. Нахимова, 2, Севастоnоль, 299011, Россия. E-mail: polyakova-acant@yandex.ru
}

РЕЗЮМЕ: Цестоды являются одними из наиболее распространенных паразитов костистых рыб в Белом море, однако ранее ни разу не были найдены у хрящевых рыб этой акватории. В данной работе мы приводим сведения о первой находке семи особей Pseudanthobothrium hanseni в Белом море у ската Amblyraja radiata. Филогенетический анализ по 28S подтвердил видовую принадлежность наших цестод. Проведено сравнение их морфологических и морфометрических признаков с описа- 
ниями P. hanseni, имеющимися в литературе. Особи P. hanseni из Белого моря меньше, чем в других районах, имеют меньшее количество семенников, а желточные фолликулы в зрелых терминальных проглоттидах не доходят до заднего края проглоттиды. Причины этих различий неясны, но определенную роль в этом может играть пониженная соленость Белого моря. Таким образом, в данной работе мы приводим первые сведения о цестодах — паразитах хрящевых рыб в Белом море и новую точку распространения $P$. hanseni.

Как цитировать эту статью: Gordeev I.I., Polyakova T.A. 2020. The first record of Pseudanthobothrium hanseni Baer, 1956 (Cestoda: Echeneibothriidae) in the White Sea // Invert. Zool. Vol.17. No.4. P.361-369. doi: 10.15298/invertzool.17.4.02

КЛЮЧЕВЫЕ СЛОВА: цестоды, скаты, Белое море, 28S рДНК, гельминты, Арктика.

\section{Introduction}

Cestodes are broadly distributed helminths parasitizing as adults a broad range of hosts including various fishes. The fauna of cestodes parasitizing teleost fishes in the White Sea is studied fairly well. It is rather poor, comprising only a few common species such as Diplocotyle olrikii Krabbe, 1874, Bothriocephalus scorpii (Müller, 1776) Cooper, 1917 species complex, Pyramicocephalus phocarum (Fabricius, 1780) Monticelli, 1890, Schistocephalus solidus (Müller, 1776) Steenstrup, 1857, Proteocephalus filicollis (Rudolphi, 1802) Weinland, 1858; Eubothrium crassum (Bloch, 1779) Nybelin, 1922 and Proteocephalus longicollis (Zeder, 1800) Nufer, 1905, as well as various cestode larvae of uncertain generic affiliation (Shulman, Shulman-Albova, 1953; Glukhova, 1956; Timofeeva, Marasaeva, 1984; Tchesunov et al., 2008). However, no cestodes from elasmobranchs have ever been reported in the White Sea.

Elasmobranchs are rare in the White Sea. Only two species of rays (the starry ray Amblyraja radiata (Donovan, 1808) and the thornback ray Raja clavata Linnaeus, 1758) and two species of sharks (the picked dogfish, Squalus acanthias Linnaeus, 1758 and the Greenland shark Somniosus microcephalus (Bloch et Schneider, 1801)) inhabit its cold low-salinity waters (Tchesunov et al., 2008). The salinity in the White Sea has sharp seasonal fluctuations, dropping below $15 \%$ in some shallow areas (Babkov, 1998).
In this paper we report a finding of the cestode Pseudanthobothrium hanseni Baer, 1956 in the starry ray A. radiata in the White Sea, thus adding a new point to the distribution of this parasite in the Arctic. We also provide morphometric data on our specimens and confirm their species affiliation with the help of molecular analysis based on the partial $28 \mathrm{~S}$ rDNA sequence.

\section{Material and Methods}

A single specimen of $A$. radiata (female, total length $11.2 \mathrm{~cm}$, disk width $8.8 \mathrm{~cm}$ ) was caught in the Velikaya Salma strait $\left(66^{\circ} 32^{\prime} 12^{\prime \prime} \mathrm{N}\right.$; $33^{\circ} 14^{\prime} 60^{\prime \prime}$ E) near the White Sea Biological Station of Lomonosov Moscow State University on July 2, 2019, during trawling with a small bottom dredge. The ray was kept in an aquarium with running seawater for several days after capture and then was dissected using standard methods (Bykhovskaya-Pavlovskaya, 1985; Klimpel et al., 2019). Cestode specimens for further molecular analysis were fixed in $96 \%$ ethanol and stored at $-18^{\circ} \mathrm{C}$. The worms for morphological study were fixed in 70 ethanol, hydrated, stained with Harris's hematoxylin, differentiated in tap water, destained in ethanol, dehydrated, cleared in methyl salicylate, and finally mounted in Canada balsam (Jensen et al., 2011). All mounts of $P$. hanseni Baer, 1956 (7 vouchers: Reg. No. 1291.C.3m.v1 - wholemounted mature worm; 1292.C.3m.v2 - wholemounted mature worm; 1293.C.3m.v3-7 - 5 scolex and proglottids; 2 hologenophores: 
1294.C.3m.v8 - separate strobila; 1295.C. $3 \mathrm{~m} . \mathrm{v} 9$ - separate strobila) were deposited in the collection of marine parasites in the A.O. Kovalevsky Institute of Biology of the Southern Seas (IBSS), Sevastopol; sample data are available at http://marineparasites.org (Dmitrieva et al., 2015). Parasitological indices follow Bush et al. (1997).

DNA extraction, amplification, sequencing, alignment and phylogenetic analysis

The total DNA was extracted from $96 \%$ ethanol-fixed adult worm using Wizard SV Genomic DNA Purification System (Promega), as recommended by the manufacturer. The nuclear 28S rRNA gene was amplified using the polymerase chain reaction (PCR) with the primers ZX-1 (5'-ACCCGCTGAATTTAAGCATAT-3'), 1500R (5'-GCTATCCTGAGGGAAACTTCG-3'), LSU 300F (5'-CAAGTACCGTGAGGGAAAGTTG-3'), 1090F (5'TGAAACACGGACCAAGG-3'), LSU_1200F (5'-CCCGAAAGATGGTGAACTATGC-3'), ECD2 (5'-CTTGGTCCGTGTTTCAAGACGGG-3'), which were described earlier (Waeschenbach, Littlewood, 2017). The initial PCR was performed in a total volume of $20 \mu \mathrm{l}$ that contained $0.25 \mathrm{mM}$ of each primer pair, $1 \mu \mathrm{l}$ DNA in water, $1 \times$ Taq buffer, $1.25 \mathrm{mM}$ dinucleotide triphosphates (dNTPs), $1.5 \mathrm{mM} \mathrm{MgCl} 2$ and 1 unit of Taq polymerase. The amplification was carried out by CJSC Eurogen (Moscow) with a 3-min denaturation hold at $94{ }^{\circ} \mathrm{C}, 40$ cycles of $30 \mathrm{~s}$ at $94{ }^{\circ} \mathrm{C}, 30 \mathrm{~s}$ at $55^{\circ} \mathrm{C}$ and $2 \mathrm{~min}$ at $72{ }^{\circ} \mathrm{C}$, and a 10 -min extension hold at $72{ }^{\circ} \mathrm{C}$. Negative and positive controls were amplified using all primers. The PCR products were directly sequenced using the ABI Big Dye Terminator v.3.1 Cycle Sequencing Kit, as recommended by the manufacturer, with the PCR primers. The PCR products were analyzed by CJSC Eurogen (Moscow). The obtained sequence of $P$. hanseni has been submitted to GenBank (NSBI) with accession number MT777179.

Partial sequence of the 28S rRNA gene, used in our study to evaluate the phylogenetic connections of our specimen, were assembled using the Geneious ver. 10.0.5 software and aligned with sequences retrieved from the Genbank database (Table 1) using the ClustalW DNA weight matrix within the MEGA 10.0.5 software alignment explorer (Kumar et al., 2018). Phylogenetic analysis of the nucleotide sequences was undertaken using the maximum likelihood (ML) and Bayesian (BI) methods. Phylogenetic trees using ML and BI methods were reconstructed using the MEGA 10.0.5 (Kumar et al., 2018) and MrBayes v. 3.6.2 software (Ronquist, Huelsenbeck, 2003), respectively. Best nucleotide substitution model for the dataset was estimated using jModelTest version 0.1.1 software (Posada, 2008). In both methods, the general time-reversible model $\mathrm{GTR}+\mathrm{G}+\mathrm{I}$ was used based on the Aikake Information Criteria (AIC). A Bayesian algorithm was performed using the Markov chain Monte Carlo (MCMC) option with ngen $=10,000,000$, nruns $=2$, nchains $=4$ and samplefreq $=100$. The burnin values were 2,500,000 for the 'sump' and 'sumt' options. The robustness of the phylogenetic relationship was estimated using bootstrap analysis with 1000 replications (Felsenstein, 1985) for ML and with posterior probabilities for BI (Ronquist, Huelsenbeck, 2003). Outgroup choice follows Healy et al. (2009).

\section{Results}

Seven cestode specimens were found in the spiral valve of the dissected starry ray. As evidenced by $28 \mathrm{~S}$ gene-based phylogenetic analysis, all of them belonged to $P$. hanseni (intensity of infection, 7) (Fig. 1). Many morphological characteristics of our specimens (Fig. 2) corresponded to the redescription of $P$. hanseni from A. radiata collected in the Western Passage (Bay of Fundy, Canada)(Randhawa et al., 2008). However, after an analysis of morphological and morphometric features of the White Sea specimens some differences were also revealed (Table 2). It is important to note that the cestodes at our disposal were mature, being represented by proglottids with a formed uterus but without eggs, while the descriptions of $P$. hanseni in the literature are based on gravid speci- 
Table 1. Data on the 28S rDNA sequences used in the phylogenetic analysis.

Таблица 1. Данные о последовательностях $28 \mathrm{~S}$ рДНК, использованных в филогенетическом анализе.

\begin{tabular}{|c|c|c|c|c|}
\hline $\begin{array}{l}\text { GenBank } \\
\text { ID }\end{array}$ & Parasite & Host & Locality & Reference \\
\hline MT525320 & $\begin{array}{l}\text { Pseudanthobothrium } \\
\text { hanseni }\end{array}$ & $\begin{array}{l}\text { Amblyraja } \\
\text { radiata }\end{array}$ & White Sea & this study \\
\hline MH688744 & $\begin{array}{l}\text { Pseudanthobothrium } \\
\text { hanseni }\end{array}$ & $\begin{array}{l}\text { Malacoraja } \\
\text { senta }\end{array}$ & $\begin{array}{l}\text { Canada: } \\
\text { Passamaquoddy } \\
\text { Bay }\end{array}$ & $\begin{array}{l}\text { Beer et al., } \\
2019\end{array}$ \\
\hline MH688743 & $\begin{array}{l}\text { Pseudanthobothrium } \\
\text { hanseni }\end{array}$ & $\begin{array}{l}\text { Amblyraja } \\
\text { doellojuradoi }\end{array}$ & $\begin{array}{l}\text { Atlantic Ocean: } \\
\text { Falkland Islands }\end{array}$ & $\begin{array}{l}\text { Beer et al., } \\
2019\end{array}$ \\
\hline MH688745 & $\begin{array}{l}\text { Pseudanthobothrium } \\
\text { hanseni }\end{array}$ & $\begin{array}{l}\text { Amblyraja } \\
\text { radiata }\end{array}$ & North Sea & $\begin{array}{l}\text { Beer et al., } \\
2019\end{array}$ \\
\hline MH688741 & $\begin{array}{l}\text { Pseudanthobothrium } \\
\text { purtoni }\end{array}$ & $\begin{array}{l}\text { Leucoraja } \\
\text { erinacea }\end{array}$ & $\begin{array}{l}\text { Canada: } \\
\text { Passamaquoddy } \\
\text { Bay }\end{array}$ & $\begin{array}{l}\text { Beer et al., } \\
2019\end{array}$ \\
\hline MH688740 & $\begin{array}{l}\text { Pseudanthobothrium } \\
\text { purtoni }\end{array}$ & $\begin{array}{l}\text { Leucoraja } \\
\text { ocellata }\end{array}$ & $\begin{array}{l}\text { Canada: } \\
\text { Passamaquoddy } \\
\text { Bay }\end{array}$ & $\begin{array}{l}\text { Beer et al., } \\
2019\end{array}$ \\
\hline KF685750 & $\begin{array}{l}\text { Pseudanthobothrium } \\
\text { sp. }\end{array}$ & $\begin{array}{l}\text { Leucoraja } \\
\text { erinacea }\end{array}$ & $\begin{array}{l}\text { Canada: St. } \\
\text { Andrews, New } \\
\text { Brunswick } \\
\end{array}$ & $\begin{array}{l}\text { Caira et al., } \\
2014\end{array}$ \\
\hline MH913263 & $\begin{array}{l}\text { Phormobothrium } \\
\text { affine }\end{array}$ & $\begin{array}{l}\text { Zearaja } \\
\text { nasuta }\end{array}$ & New Zealand & $\begin{array}{l}\text { Bennett et } \\
\text { al., } 2019\end{array}$ \\
\hline MH688748 & $\begin{array}{l}\text { Echeneibothrium } \\
\text { multiloculatum }\end{array}$ & $\begin{array}{l}\text { Zearaja } \\
\text { chilensis }\end{array}$ & $\begin{array}{l}\text { Atlantic Ocean: } \\
\text { Falkland Islands }\end{array}$ & $\begin{array}{l}\text { Beer et al., } \\
2019\end{array}$ \\
\hline MH688750 & $\begin{array}{l}\text { Echeneibothrium } \\
\text { vernetae }\end{array}$ & $\begin{array}{l}\text { Leucoraja } \\
\text { erinacea }\end{array}$ & $\begin{array}{l}\text { Canada: } \\
\text { Passamaquoddy } \\
\text { Bay }\end{array}$ & $\begin{array}{l}\text { Beer et al., } \\
2019\end{array}$ \\
\hline MH688751 & $\begin{array}{l}\text { Echeneibothrium } \\
\text { canadensis }\end{array}$ & $\begin{array}{l}\text { Amblyraja } \\
\text { radiata }\end{array}$ & $\begin{array}{l}\text { Canada: } \\
\text { Passamaquoddy } \\
\text { Bay }\end{array}$ & $\begin{array}{l}\text { Beer et al., } \\
2019\end{array}$ \\
\hline KF685901 & $\begin{array}{l}\text { Scyphophyllidium cf. } \\
\text { giganteum }\end{array}$ & $\begin{array}{l}\text { Galeorhinus } \\
\text { galeus }\end{array}$ & $\begin{array}{l}\text { New Zealand: } \\
\text { Chatham Rise }\end{array}$ & $\begin{array}{l}\text { Caira et al., } \\
2014\end{array}$ \\
\hline AF286930 & Litobothrium janovyi & $\begin{array}{l}\text { Alopias } \\
\text { superciliosus }\end{array}$ & Mexico & $\begin{array}{l}\text { Waeschen- } \\
\text { bach et al., } \\
2007\end{array}$ \\
\hline
\end{tabular}

mens (Williams, 1966; Randhawa et al., 2008). Therefore, only the morphology of mature proglottids was taken into account in our further analysis.

\section{Discussion}

Both molecular and morphological analyses confirmed that our specimens belonged to $P$. hanseni. However, some differences from the descriptions of $P$. hanseni available in the literature were also found. To note, in this study we used only some of the numerous sequences of $P$. hanseni and other representatives of the family Echeneibothriidae available in GenBank (Fig. 1). Therefore, our tree cannot be used for discussing the systematics of the genus Pseudanthobothrium. 


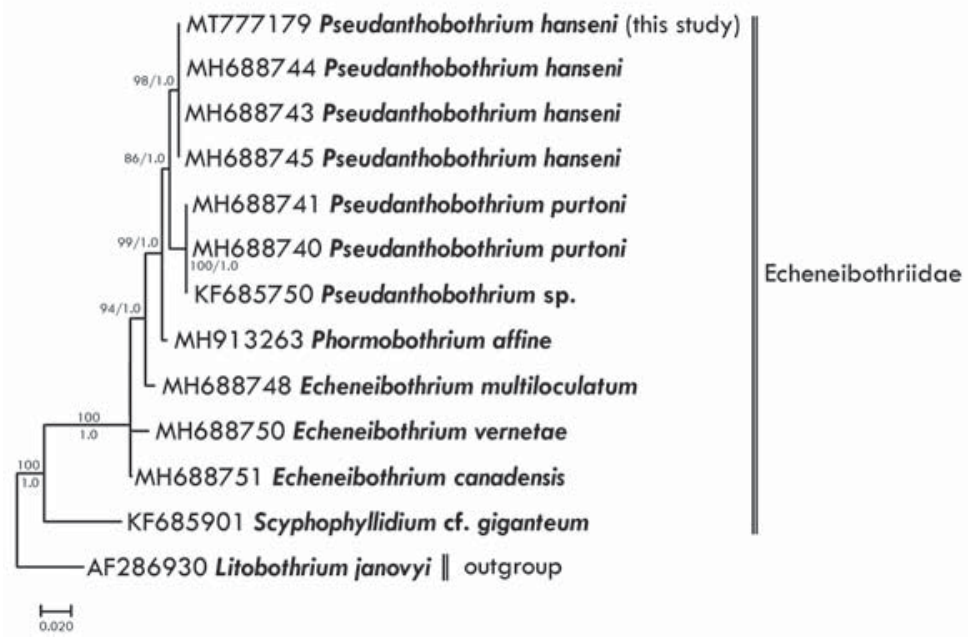

Fig. 1. Phylogenetic relationships of Pseudanthobothrium hanseni based on 1499 bp 28S rDNA sequence (GTR + G+I model). Numbers at nodes indicate bootstrap values/Bayesian posterior probabilities.

Рис. 1. Филогенетические отношения Pseudanthobothrium hanseni, построенные на основании частичных последовательностей $28 \mathrm{~S}$ рДНК (1499 п.н.), модель GTR + G+I. Число в узлах обозначают поддержку бутстрепа/байесовские апостериорные вероятности.

Pseudanthobothrium hanseni is recorded in the North Atlantic from the starry ray A. radiata and Malacoraja senta in the Atlantic waters of Canada (Randhawa et al., 2007; Randhawa et al., 2008; Randhawa, Burt, 2008), and the spinytail skate Bathyraja spinicauda (Jensen, 1914) in the north-eastern Norwegian Sea (Rokicki et al., 2001). Pseudanthobothrium purtoni Randhawa, Saunders, Scott \& Burt, 2008 was primarily described from the same area in the North Atlantic, but according to our own data on helminths of Bathyraja sp. ('Bathyraja sexoculata') in the Simushir Island area (Gordeev, Polyakova, 2020), it also inhabits the North Pacific. Thus, the distribution area of the genus Pseudanthobothrium seems to be underestimated. It may be broadly present in the bottom ecosystems in the Arctic seas and elsewhere.

Fig. 2. Pseudanthobothrium hanseni ex Amblyraja radiata from the White Sea. A - whole worm; B scolex; $\mathrm{C}$ - mature, terminal proglottid. Scale bars: $\mathrm{A}-200 \mu \mathrm{m} ; \mathrm{B}-\mathrm{C}-100 \mu \mathrm{m}$.

Рис. 2. Pseudanthobothrium hanseni от Amblyraja radiata из Белого моря. А - общий вид; В сколекс; C - зрелая, терминальная проглоттида. Масштаб: А - 200 мкм; B-C - 100 мкм.

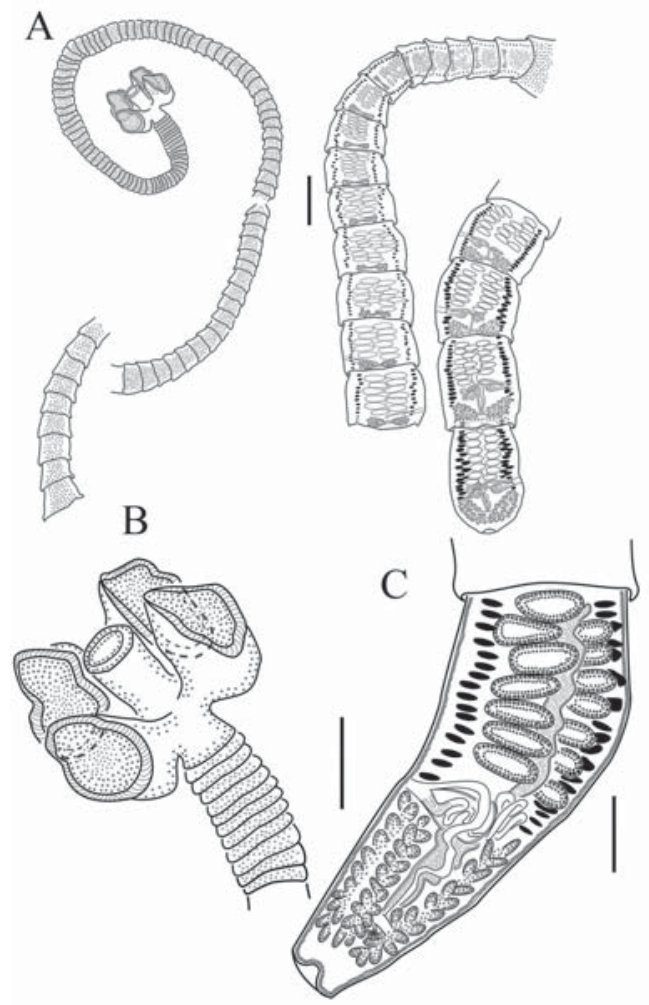


Table 2. Morphological characteristics of Pseudanthobothrium hanseni Baer, 1956 ex Amblyraja radiata (Donovan, 1808) from different areas.

Таблица 2. Морфологические характеристики Pseudanthobothrium hanseni Baer, 1956 от Amblyraja radiata (Donovan, 1808) из разных районов.

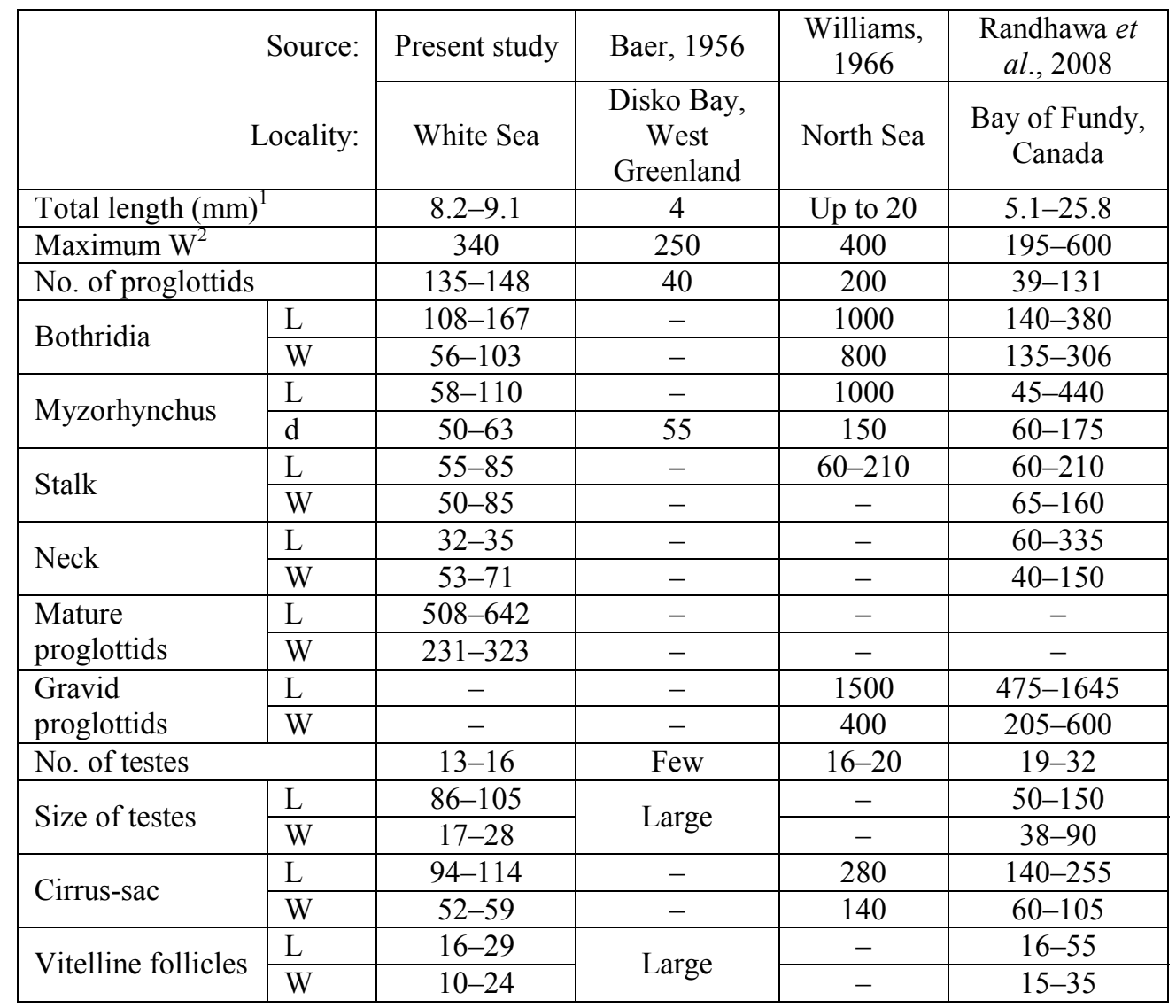

${ }^{1}$ All measurements in micrometres unless otherwise indicated.

${ }^{2}$ Abbreviations: No. - number; $\mathrm{L}$ - length; $\mathrm{W}$ - width, $\mathrm{d}$ - diameter.

Beer et al. (2019) recorded two species of Pseudanthobothrium in Amblyraja doellojuradoi (Pozzi, 1935) caught in the Falkland Islands area. Apparently, this genus tends to be associated with the polar and sub-polar waters.

Amblyraja radiata is a very common ray in the North Atlantic and the seas adjacent to the Arctic Ocean (Last et al., 2016). Throughout this extensive area, it serves as a host of at least 19 species of onchoproteocephalidean, phyllobothriidean, rhinebothriidean, diphyllidean, and trypanorhynchean cestodes (Pollerspöck, Straube, 2019). The freshened environment of the White Sea makes possible the presence of the euryhaline species in marine communities (Tchesunov et al., 2008), while truly marine fish come from the Barents Sea mostly through poorly studied bottom recesses, in which normal oceanic salinity is preserved. This may be the reason why a parasite of an elasmobranch in the White Sea was recorded in our study for the first time.

Ecological and biological features of the elasmobranchs such as feeding behavior, age, size, depth and geographical distribution, play an important role in their co-evolution with 
cestodes (Caira, Bardos, 1996; Klimpel et al., 2003; Palm, 2004; Beer et al., 2019). In this study, we cannot explain with certainty the morphometric differences between $P$. hanseni from the White Sea and other areas (Table 2). Some role may be played by salinity, which in the White Sea (Babkov, 1998) could be twice or more lower than in habitats of the previously studied hosts of $P$. hanseni (Baer, 1956; Williams, 1966; Randhawa et al., 2008). The White Sea is not isolated from the ocean, but the capture of rays there is quite rare. This might mean that the environmental conditions there are on the verge of tolerance of marine rays. This, in turn, is likely to affect their parasites.

The length of the strobila of cestodes in the present study could not be used as a diagnostic sign, since the specimens were at different stages of development. However, the mature cestodes from the White Sea in our study had a greater number of proglottids (135-148) than gravid P. hanseni (39-131) (Randhawa et al., 2008). Our specimens also had fewer testes, 1316 vs. 19-32 in Randhawa et al. (2008) vs. 1620 in Williams (1966). In the mature proglottids of worms under study, the yolk follicles were located in two lateral bands extending from the anterior end of the proglottid to the anterior end of the ovary, without reaching the posterior end of the proglottid (Fig. 2). Moreover, in the figures of mature proglottids in the description of $P$. hanseni in the work of Williams (1966: fig. 95), as well as in mature and gravid proglottids in the work of Randhawa et al. (2008: figs 2,3), yolk follicles extend from the anterior to posterior end of the proglottids, without interruption at the level of the ovary. However, according to the redescription of $P$. hanseni in Randhawa et al. (2008) "Vitelline follicles ....., arranged in 2 paired lateral bands anterior to ovary, extending as 2 single lateral bands posterior to anterior margin of the ovary along length of proglottis (Fig. 2A)." Thus, the location of yolk follicles in the text of the description of $P$. hanseni are somewhat inconsistent with the details shown in Figure 2 (see Randhawa et al., 2008). In our specimens the yolk vitelline follicles reached the posterior margin of proglottids only in im- mature proglottids. A relatively low intensity of infection (7 worms/host) must be associated with the small size and, accordingly, age of the examined host specimen. As elasmobranchs grow, their diet changes, and their infection with cestodes increases as a result (Randhawa et al., 2008; Gordeev, Polyakova, 2020). All other cestode species recorded in the White Sea (Tchesunov et al., 2008; see above) parasitize at the adult stage teleosts, birds, and mammals which, unlike rays, are common in the White Sea. It is therefore unsurprising that the starry ray examined in our study harbored only a few individuals of a single parasite species.

\section{Acknowledgements}

The authors are grateful to Drs Alexander Tzetlin, Polina Belova, Elena Vortsepneva, Andrey Prudkovsky, and Ekaterina Bogomolova (Lomonosov Moscow State University) for their help in sampling, as well as Natalia Lentsman (St. Petersburg State University, MSc in Biology, MA in English Language and Literature) for proofreading.

\section{Funding}

The work was supported by Russian Academy of Sciences \#AAAA-A18-1180208900742

\section{Compliance with ethical standards}

Conflict of Interest: The authors declare that they have no conflict of interest.

Ethical approval: This article does not contain any studies with animals performed by any of the authors.

Sampling and field studies: All necessary permits for sampling and observational field studies have been obtained by the authors from the competent authorities and are mentioned in the acknowledgements, if applicable.

\section{References}

Babkov A.I. 1998. [Hydrology of the White Sea.] St. Petersburg: ZIN RAN. 94 p. [In Russian]

Baer J.G. 1956. Parasitic helminths collected in West Greenland // Meddelelser om Grønland Udgivne af 
Kommissionen for Videnskabelige Undersogelser i Grönland. Vol.124. P.1-55.

Beer A., Ingram T., Randhawa H.S. 2019. Role of ecology and phylogeny in determining tapeworm assemblages in skates (Rajiformes) // Journal of Helminthology. Vol.93. No.6. P.738-751. doi: 10.1017/ S0022149X18000809

Bennett J., Jorge F., Poulin R., Randhawa H. 2019. Revealing trophic transmission pathways of marine tapeworms // Parasitology Research. Vol.118. No.5. P.1435-1444. doi: 10.1007/s00436-019-06264-3

Bush A.O., Lafferty K.D., Lotz J.M., Shostak A.W. 1997. Parasitology meets ecology on its own terms: Margolis et al. revisited // Journal of Parasitology. Vol.83. P.575-583. doi: 10.2307/32842 27

Bykhovskaya-Pavlovskaya I.E. 1985. [Parasites of fishes. The Manual.] Leningrad: Nauka. 124 p. [In Russian]

Caira, J.N., Bardos, T. 1996. Further information on Gymnorhyncus isuri (Trypanorhyncha: Gymnorhynchidae) from the shortfin mako shark // Journal of Helmintological Society of Washington. Vol.63. P.188-192.

Caira J.N., Jensen K., Waeschenbach A., Olson P.D., Littlewood D.T.J. 2014. Orders out of chaos-molecular phylogenetics reveals the complexity of shark and stingray tapeworm relationships // International Journal for Parasitology. Vol.44. No.1. P.55-73. doi: 10.1016/j.ijpara.2013.10.004

Dmitrieva E.V., Lyakh A.M., Kornyychuk Yu.M, Polyakova T.A., Popyuk M.P. 2015. IMBR Collection of marine parasites: the collection of marine parasites maintained by the Institute of Marine Biological Research. Available at: www.marineparasites.org. (Accessed 11 June 2020).

Felsenstein J. 1985. Confidence limits on phylogenies: an approach using bootstrap // Evolution. Vol.39. P.783791. doi: 10.1111/j.1558-5646.1985.tb00420.x

Glukhova V.M. 1956. [Parasitofauna of flatfish of the White Sea.] // Trudy Karelo-Finskogo Filiala Akademii Nauk SSSR. Vol.4. P.27-49 [in Russian].

Gordeev I., Polyakova T. 2020. Helminths and the stomach contentment of Bathyraja sp. (Rajiformes: Arhynchobatidae) in the Simushir Island area (Pacific Ocean)// Journal of Asia-Pacific Biodiversity. Vol.13. No.2. P.306-309. doi: 10.1016/j.japb.2020.03.005

Healy C.J., Caira J.N., Jensen K., Webster B.L., Littlewood D.T.J. 2009. Proposal for a new tapeworm order, Rhinebothriidea // International Journal for Parasitology. Vol.39. No.4. P.497-511. doi: 10.1016/ j.ijpara.2008.09.002

Jensen K., Nikolov P., Caira J.N. 2011. A new genus and two new species of Anteroporidae (Cestoda: Lecanicephalidea) from the darkspotted numbfish, Narcine maculata (Torpediniformes: Narcinidae), off Malaysian Borneo // Folia Parasitologica. Vol.58. No.2. P.95-107. doi: 10.14411/fp.2011.010

Klimpel S., Kuhn T., Münster J., Dörge D.D., Klapper R., Kochmann J. 2019. Parasites of marine fish and cephalopods. New York. Springer International Publishing. 169 p. doi: 10.1007/978-3-030-16220-7
Klimpel S., Palm H.W., Seehagen A. 2003. Metazoan parasites and food composition of juvenile Etmopterus spinax (L., 1758) (Dalatiidae, Squaliformes) from the Norwegian Deep // Parasitology Research. Vol.89. P.245-251.

Kumar S., Stecher G., Li M., Knyaz C., Tamura K. 2018. MEGA X: Molecular evolutionary genetics analysis across computing platforms // Molecular Biology and Evolution. Vol.35. No.6. P.1547-1549. doi: 10.1093/ molbe $\mathrm{v} / \mathrm{msy} 09$

Last P., White W.T., de Carvalho M.R., Séret B., Stehmann M.F. (eds.) 2016. Rays of the World. Clayton (Australia). CSIRO Publishing. 790 p. doi: 10.1111/ avj. 12586

Palm H.W. 2004. The Trypanorhyncha Diesing, 1863. Bogor: PKSPL-IPB Press. 710 p.

Pollerspöck J., Straube N. 2019. Host-Parasite List and Parasite-Host List of Elasmobranchs. Available at https://www.shark-references.com. (Accessed 19 May 2020).

Posada D. 2008. jModelTest: phylogenetic model averaging // Molecular Biology and Evolution. Vol.25. P.1253-1256. doi: 10.1093/molbev/msn083

Randhawa H.S., Burt M.D.B. 2008. Determinants of host specificity and comments on attachment site specificity of tetraphyllidean cestodes infecting rajid skates from the northwest Atlantic // Journal of Parasitology. Vol.94. No.2. P.436-461. doi: 10.1645/GE-1180.1

Randhawa H.S., Saunders G.W., Burt M.D.B. 2007. Establishment of the onset of host specificity in four phyllobothriid tapeworm species (Cestoda: Tetraphyllidea) using a molecular approach // Parasitology. Vol.134. No.9. P.1291-1300. doi: 10.1017/ S0031182007002521

Randhawa H.S., Saunders G.W., Scott M.E., Burt M.D.B. 2008. Redescription of Pseudanthobothrium hanseni Baer, 1956 and description of P. purtoni n. sp. (Cestoda: Tetraphyllidea) from different pairs of rajid skate hosts, with comments on the host-specificity of the genus in the Northwest Atlantic // Systematic Parasitology. Vol.70. No.1. P.41-60. doi: 10.1007/ s11230-007-9122-6.

Rokicki J., Bjelland O., Berland B. 2001. Some helminth and copepod parasites of three rajid species from the continental slope of the north-eastern Norwegian Sea // Acta Parasitologica. Vol.46. P.12-17.

Ronquist F., Huelsenbeck J.P. 2003. MrBayes 3: Bayesian phylogenetic inference under mixed models // Bioinformatics. Vol.19. P.1572-1574. doi: 10.1093/bioinformatics/btg 180

Shulman S.S., Shulman-Albova R.E. 1953. [Parasites of fish of the White Sea.] Moscow-Leningrad. Izdatel'stvo akademii nauk SSSR. 198 p. [In Russian]

Tchesunov A.V., Kaljakina N.M., Bubnova E.N. (eds.). 2008. [A catalogue of biota of the White Sea Biological Station of the Moscow State University.] Moscow. KMK Scientific Press. 392 p. [In Russian]

Timofeeva S.V., Marasaeva E.F. 1984. [Parasitofauna of two forms of cod of Kandalaksha Bay of the White Sea.] // Ju.I. Polyanskiy (ed.). Ekologo-parazitolog- 
icheskie issledovaniya severnykhh morey. Apatity: Kol'skij filial AN SSSR. P.62-76 [in Russian].

Waeschenbach A., Littlewood D.T.J. 2017. A molecular framework for the Cestoda // J.N. Caira, K. Jensen (eds.). Planetary Biodiversity Inventory (2008-2017): Tapeworms from the vertebrate bowels of the Earth. Lawrence, KS USA. University of Kansas, Natural History Museum, Special Publucation. No.25. P.431451.

Waeschenbach A., Webster B.L., Bray R.A., Littlewood D.T.J. 2007. Added resolution among ordinal level relationships of tapeworms (Platyhelminthes: Cesto- da) with complete small and large subunit nuclear ribosomal RNA genes // Molecular Phylogenetics and Evolution. Vol.45. No.1. P.311-325. doi: 10.1016/ j.ympev.2007.03.019

Williams H.H. 1966. The ecology, functional morphology and taxonomy of Echeneibothrium Beneden, 1849 (Cestoda: Tetraphyllidea), a revision of the genus and comments on Discobothrium Beneden, 1870, Pseudanthobothrium Baer, 1956, and Phormobothrium Alexander, 1963 // Parasitology. Vol.56. P.227-285. doi: $10.1017 / \mathrm{S} 0031182000070864$

Responsible editor A.S. Petrunina 